\title{
The Extra-floral Nectaries of the Genus Polygonum.
}

\author{
BY \\ E. J. SALISBURY, B.Sc., \\ Quain Student in Biology (Botany), University of London, University College.
}

With Plate XVI, and six Figures in the Text.

THE present research was undertaken with a view to ascertaining the function of the glands which occur on the underside of the leafcushion in various species of Polygonum. The following species have been under observation, viz. :-

Polygonum baldschuanicum, P. cilinodum, P. compactum, P. Convolvulus, $P$. cuspidatum, $P$. multiflorum, $P$. sachalinense, and $P$. scandens.

All the above agree in possessing leaves which are variations upon the cordate-saggitate type and are either herbaceous or annual.

The only woody species is $P$.baldschuanicum, which produces climbing shoots that die back in the winter. Polygonum cilinodum, $P$. Convolvulus, and $P$. scandens are also of climbing habit.

The extra-floral nectaries of $P$. cuspidatum have been described by Delpino (5); those of $P$. baldschuanicum, P. Convolvulus, and P. multiflorum by Schwendt (15), and those of $P$. sachalinense by Ono (12). The two latter papers were published during the course of the present research. Detailed descriptions of the above species need not therefore be included.

For convenience, the paper is divided into the following sections, viz. I, General ; II, Special ; III, Microchemical ; IV, Physiological ; V, Summary and General Conclusions.

\section{General.}

The extra-floral nectaries are oval, triangular, or circular depressions. In all except the circular nectary of $P$. cilinodum the depressions are boatshaped. The nectaries lie in the plane of symmetry of the leaf and are situated upon the underside of the base of the petiole just below the abscission layer which is differentiated at an early stage (Pl. XVI, Fig. 4). Polygonum cilinodum is, however, an exception to this rule, for in this species where, though the glands were fully developed, no abscission layer could be recognized. Like most nectaries these stand in close relation

[Annals of Botany, Vol. XXIII. No. XC. April, 1909.] 
to the vascular system. The vascular supply of the petiole is therefore of some interest and attains greater significance when viewed in the light of the physiological experiments to be described later on. In general, the petiole of the Polygonums is convex or angled upon its lower surface and concave or grooved upon its upper.

The bundles form a dorsal arc which is closed by a bundle or bundles placed ventrally and which of course have the xylem directed inwards. (The terms dorsal and ventral are applied to the lower and upper surface of the leaf, respectively.)

In the simpler types of petiole the bundles are six in number, so that the ventral and one of the five dorsal bundles lie in the median plane, and
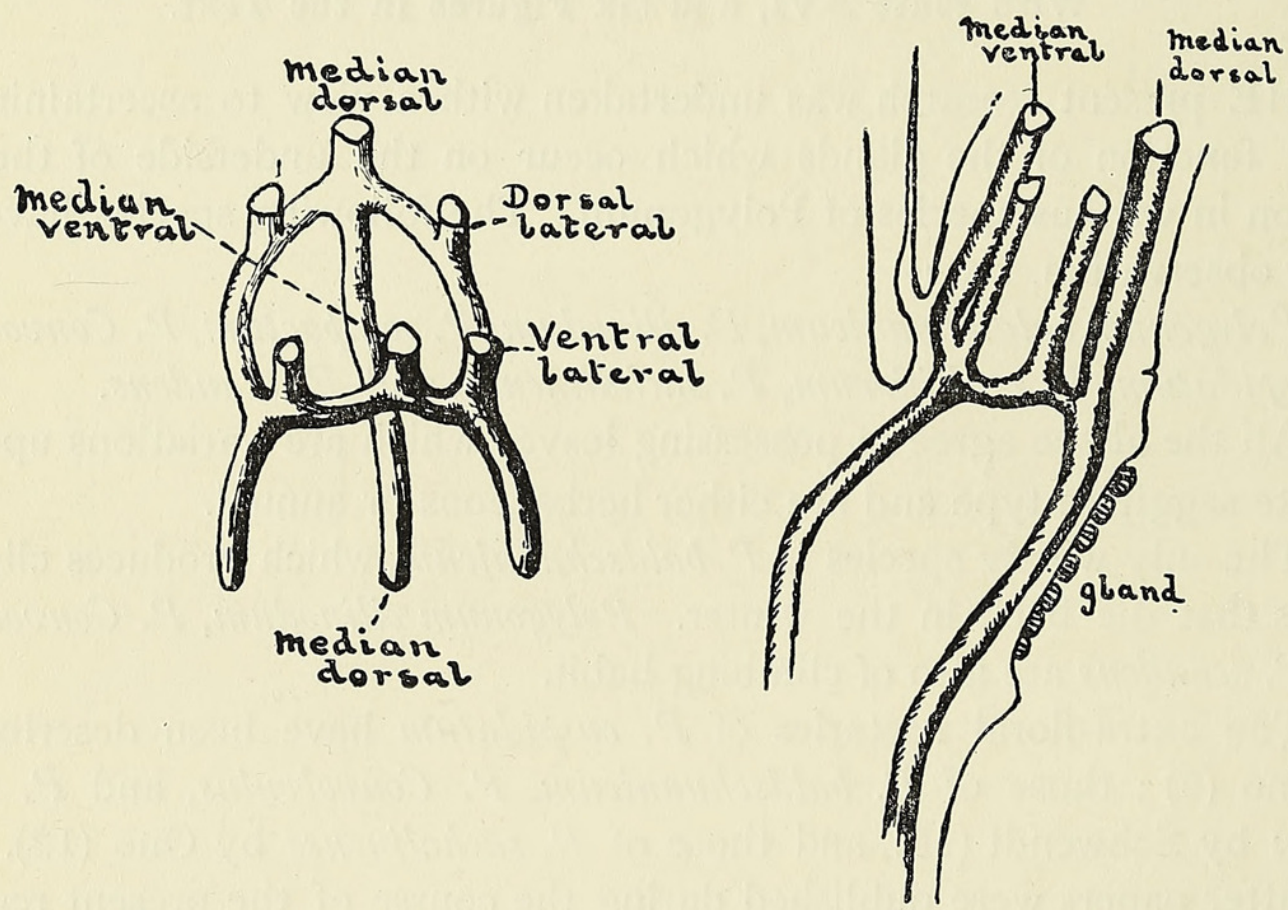

FIG. I. Vascular supply of petiole in Polygonum multiflorum. The bundles passing to the ochrea have been omitted.

the other four are arranged symmetrically with regard to these. (The pair of bundles which occupy the upper angles of the petiole are frequently reduced.)

In the more complex forms the arrangement is the same, but owing to subdivision the bundles are more numerous.

It is opposite the dorsal median bundle that the nectary is situated (Text-fig. I).

Around the nectary the tissue is somewhat raised, and may even slightly overhang, especially at the upper edge. For convenience of description this will be termed the lip.

The nectaries are fully developed and function before the leaf unfolds: large drops of secretion were observed upon nectaries of P. cuspidatum when the lamina was not quite $2 \mathrm{~mm}$. in length. 
Winter buds upon their emergence in the spring have actively secreting nectaries upon bud-scales which possess no lamina.

In only one species, viz. P. Convolvulus were seedlings obtained; and these showed variations in the occurrence of the nectaries.

In no case were they present upon the cotyledons, but whilst they appear to be normally present on the petiole of the first leaf, occasional specimens had no nectary till the second or third leaf was reached. The depressions forming the nectaries are lined with secretory trichomes which form a closely packed layer over the whole surface. The trichomes or unit structures of the nectary consist of three parts.

The lowest or basal portion consists of large sac-like thin-walled cells, which with their neighbours form an almost continuous layer one cell deep, and for each gland number four or more in a single story (Text-fig. 2, $b$, on left).

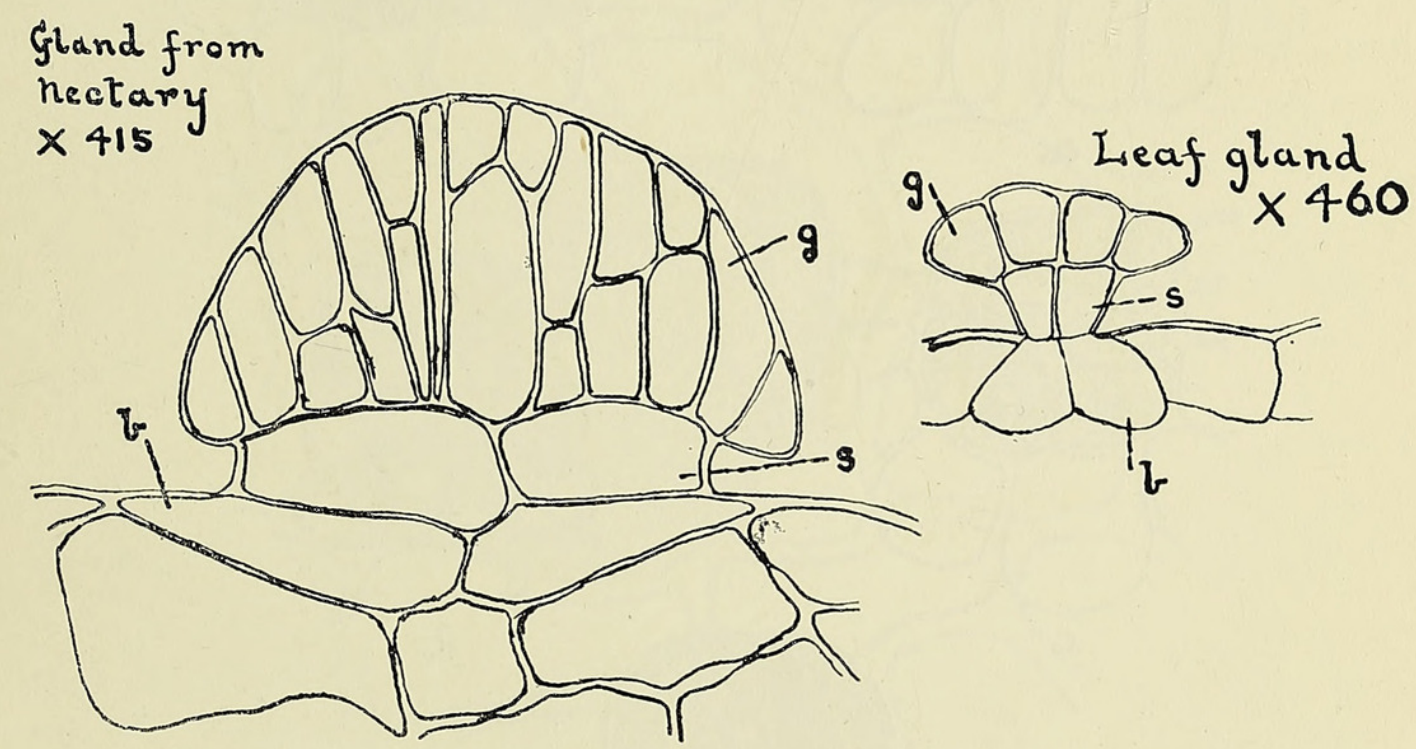

Fig. 2. Nectary-and leaf-glands of Polygomum compactum. g. gland cells; s. stalk cells; b. basal cells.

The middle layer is also one cell deep, and consists of flattened cells whose vertical walls are thickened, the horizontal walls-separating them on the one hand from the basal cells, and on the other from the gland cellsremain thin (Text-fig. $2, s$ ).

The gland cells forming the third portion are usually not more than one cell deep, but may become subdivided by transverse walls ; they form an enlarged head of numerous cells elongated in the vertical direction and with comparatively thin walls (Text-fig. $2, g$ ). This type of structure is frequent in secreting trichomes, and also finds its parallel in the hydathodes of Piperaceae, Bignoniaceae, and species of Artocarpus as was shown by Haberlandt ( 8 , p. 420 ).

As regards the cytological details, they are those characteristic for secretory cells in general; the gland cells when young are completely 
filled with a dense granular and highly refractive cytoplasm and possess large nuclei. At maturity they become markedly vacuolate. This vacuolation was observed by Gardiner ( 7$)$ in the gland cells of Dionaea, and more recently, Miss Huie has shown that the gland cells of Drosera exhibit vacuolation, which is most marked at the period of secretion (9). See also Saunders (13).

The development of the nectaries was studied in P.cuspidatum, and agrees with that described by Schwendt (15, p. 250) for Muchlenbeckia sagittifolia.

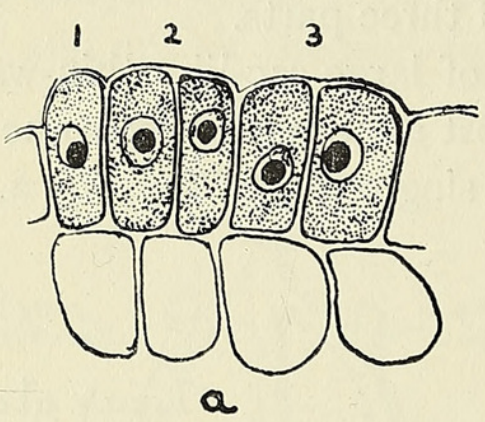

a
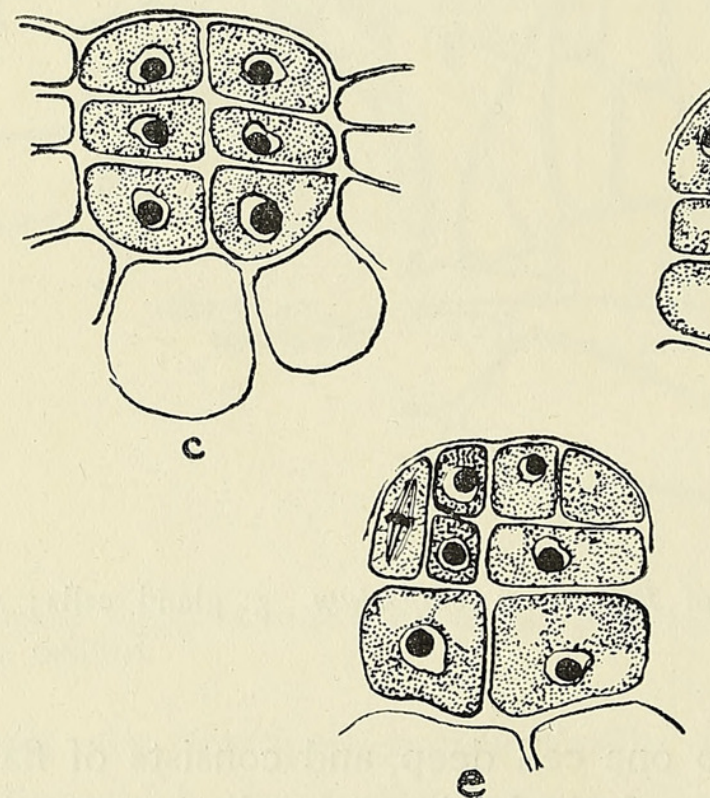

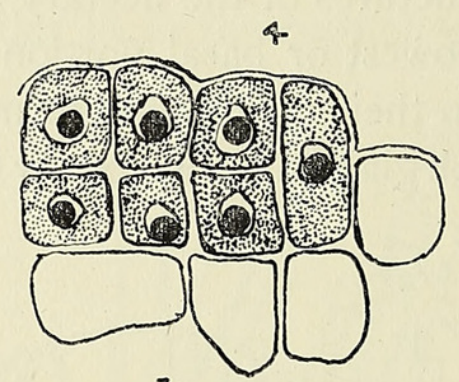

飞

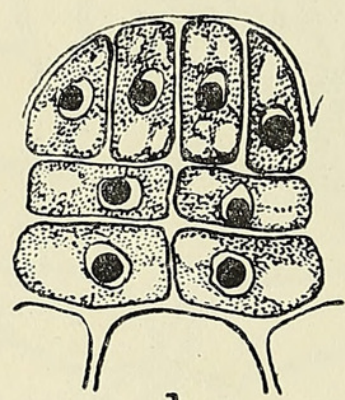

2

FIG. 3. Development of nectary glands in Polygonum cuspidatum, shown in vertical section. The successive stages are seen in $a, b, c, d$. In $e$, the longitudinal division of the glandular portion has taken place before the completion of the last horizontal division. The figures I-4 denote successive stages in development. $\quad \times 460$.

The development of the trichomes starts from the centre of the nectary and passes to the periphery. It begins with the radial division of the gland mother-cells in two planes at right angles to one another. Division parallel to the surface of the nectary then takes place, and we thus have formed an upper and a lower story, each of four cells. The cells of the upper group again divide horizontally, and we thus have formed the three series representing the basal, stalk, and gland cells. This sequence may, however, be subject to slight variation (Text-fig. $3, e$ ). 
Further subdivision generally takes place in the glandular portion as this reaches maturity; the walls are usually vertical but sometimes horizontal or inclined. Further subdivision of the stalk and basal cells is not infrequent, but does not take place to the same extent as in the secretory region.

In all the species enumerated, and in others not bearing extra-floral nectaries, isolated glands which secrete gum occur upon the ochrea, petioles, stems, and leaf-blades (Pl. XVI, Fig. $5, g$ ).

The structure of these glands is in all essentials identical with that of the nectary-units just described (see Text-fig. 2).

They arise as epidermal papillae, and follow the same course of

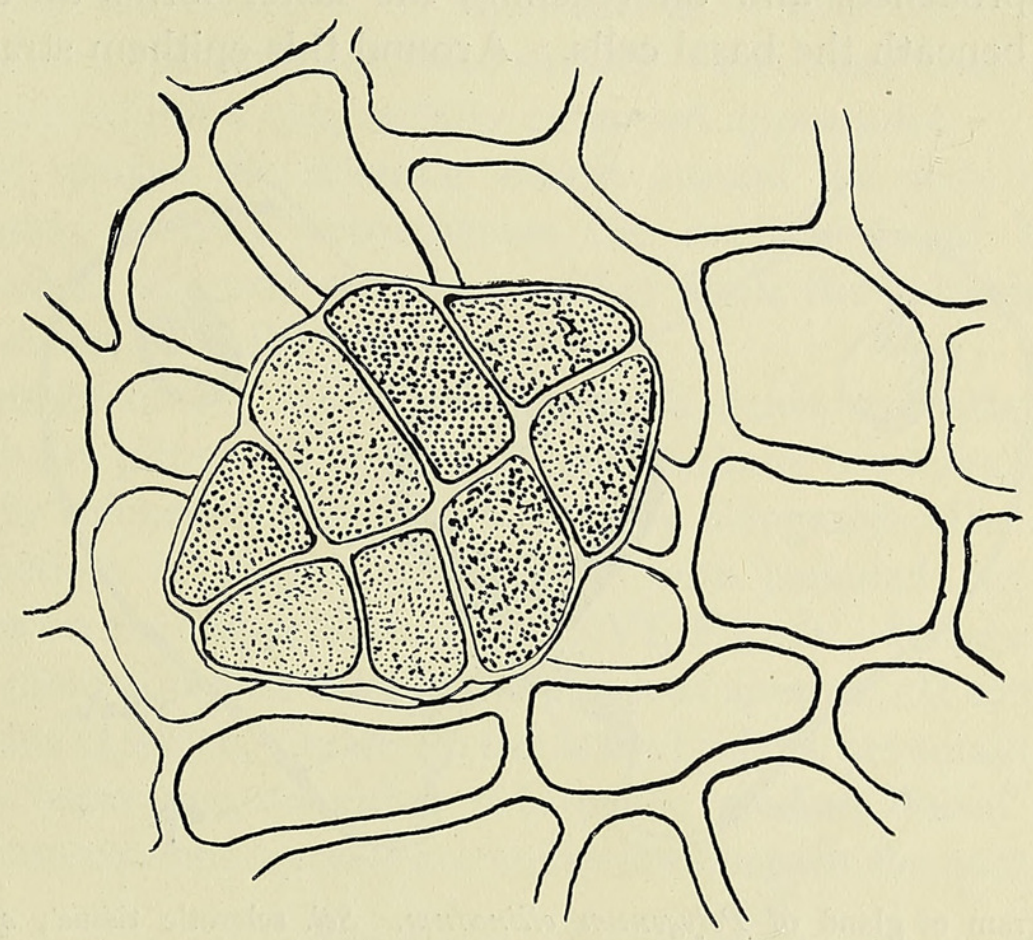

FIG. 4. Gland from ochrea of Polygonum sachalinense. $\quad \times 580$.

development as those of the nectary; subdivision is however much less, and practically confined to the secretory portion.

These, like the foregoing, function long before the leaf unrolls, and mostly fall off before the organs reach maturity.

It is interesting to note in this connexion that similar glands secreting a mucilagenous substance and probably functioning as hydathodes have been described by Areschoug (1) on leaves of various species of Mangroves.

\section{Special.}

Polygonum cilinodum (P1. XVI, Fig. I).

The nectaries in this species are circular in outline with a diameter of about $0.63 \mathrm{~mm}$. They are saucer-shaped depressions surrounded by a well-marked lip, which slightly overhangs the concavity. 
The lip consists of slightly thickened cells covered by an epidermis of radially elongated elements and strongly thickened external walls, whilst near the nectary its cells are sometimes divided tangentially. The median dorsal leaf-trace accompanied by a sclerenchyma sheath, which is a continuation of that which surrounds the stele of the stem, passes close beneath the nectary.

Opposite the nectary the sclerenchyma sheath is pierced, and through this opening there passes from the bundle to the nectary a band of smallcelled tissue with dense contents, large nuclei, and strongly thickened walls, which latter are deeply pitted (Pl. XVI, Fig. 2, sp).

This, which we may term the epithem tissue, broadens out as the nectary is approached, and on reaching the latter forms an almost continuous layer beneath the basal cells. Around this epithem strand is large-

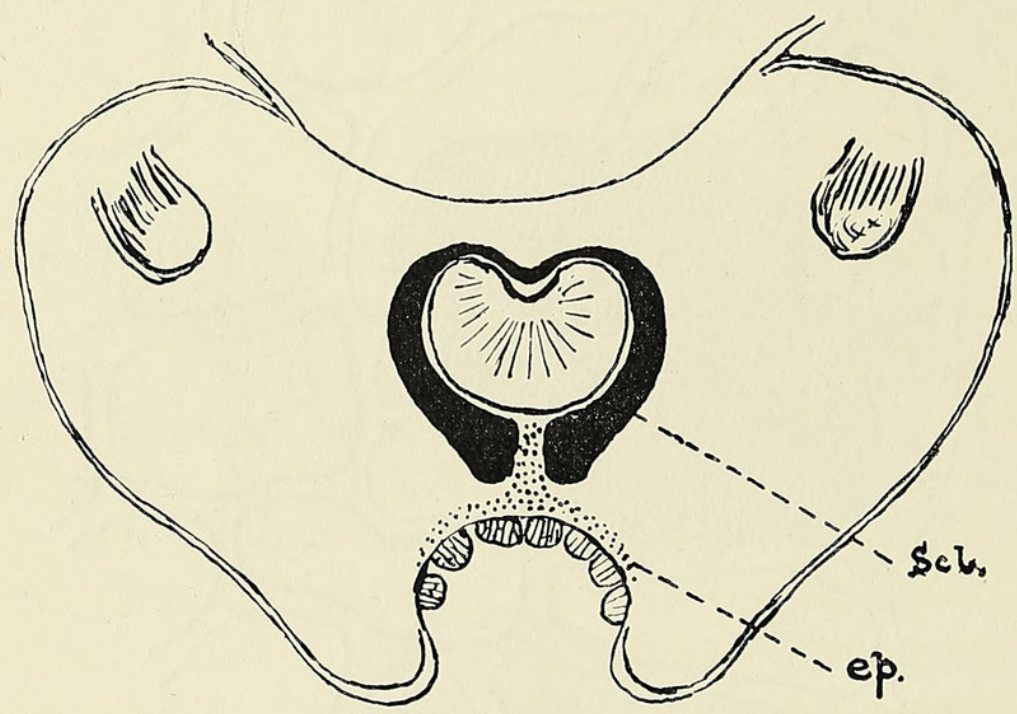

FIg. 5. Diagram of gland of Polygonum cilinodum. Scl. sclerotic tissue; ep. small-celled epithem.

celled parenchyma which in a transverse section appears as two groups to right and left of the small-celled tissue (Pl. XVI, Fig. $2, l p$ ).

The secretory trichomes themselves are in this species much more complex than in any of the others examined; this is due to increased division, and applies not only to the secretory but also to the stalk and basal regions.

The glandular head shows both radial and transverse division, the latter may take place in some or all of its cells.

The petiole of this species is rounded in transverse section with a slight concavity above (Pl. XVI, Fig. 9). It contains six bundles, the five forming the dorsal arc are of nearly equal size, whilst the ventral bundle is larger. A noticeable feature in this species is its fringed ochrea. The hairs which arise from the base of the latter are directed downwards and 
might perhaps prevent any small insect that had been attracted by the nectar from climbing the stem further.

Sphaerocrystals of calcium oxalate are generally distributed throughout the plant, and are always relatively crowded in the young organs and beneath the nectaries.

The blades, besides possessing mucilage-secreting glands, have cells which appear to contain mucilage scattered at intervals in the epidermis.

\section{Polygonum compactum.}

In this species the nectary is an oblong; almost rectangular, shallow, flattened depression. It measures about $\mathrm{I} \times 0.75 \mathrm{~mm}$. (Pl. XVI, Fig. II).

The glandular heads of the trichomes show both radial and tangential subdivision, and the stalk cells also divide. The basal cells seldom appear to do so, and exhibit a tangentially extended appearance.

In this species the sclerotic sheath around the stele of the stem is discontinuous; it only accompanies the median dorsal bundle of the petiole as slight sclerotic strands on either flank, the epithem tissue therefore abuts direct upon the phloem.

It consists of 2-3 layers of cells with dense contents and sclerized walls which are pitted. The lip does not overhang but has a well-developed and strongly thickened epidermis of radially elongated cells.

The petiole is roughly rectangular with rounded corners and with three ridges on the upper surface (Pl. XVI, Fig. 7). Its vascular supply is somewhat more complex than in the previous species. It consists of twelve bundles-two of which, situated in the lateral ridges, are small, and two other small ones occur one on either side of the median dorsal strand. Here again, calcium oxalate crystals are numerous beneath the nectary.

\section{Polygonum sachalinense.}

This species, which is by far the largest of those investigated, has a much more complex petiole structure (Pl. XVI, Fig. 6).

In transverse section as many as nineteen or twenty bundles may be present. Associated with this large size and consequent increase of vascular supply we find an augmented system of extra-floral nectaries; a large one about $2 \times 1 \mathrm{~mm}$. upon the abaxial face of the leaf-cushion, and from 2-4 paired nectaries of ellipsoid form situated above the main lateral veins of the leaf-base, at the points where they emerge from the stem. All these glands are present on the youngest leaves. The accessory glands measure about $0.25 \times 0.75 \mathrm{~mm}$., and except in point of size their structure agrees with the main nectary. The latter is sunk about a millimetre below the surface, and is an almost flat depression (P1. XVI, Fig. 4). The basal cells are separated from the phloem of the underlying bundles by from 3-4 layers of cells which are strongly sclerized and deeply pitted (Text-fig. 6). 
These cells appear to be of two kinds, some show a deeply stained protoplasm, the rest stain but faintly and contain large nuclei. The staining

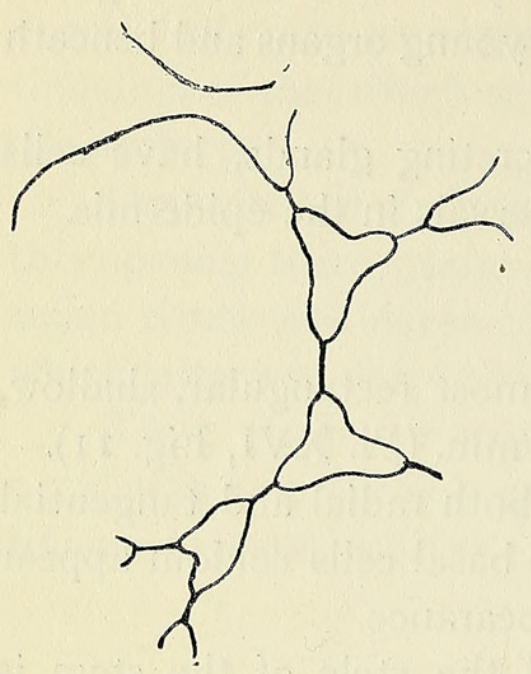

FIG. 6. Pitted epithem of Poiggonum sachalinense. reagents used being Methyl blue and Kleinenberg's hematoxylin and safranin.

\section{Polygonum multiflorum.}

The nectary here is triangular in form; only slightly depressed, and with poorly differentiated lips. Immediately beneath the nectary are from 2-3 layers of sclerized and pitted cells, between these and the bundle are parenchymatous cells interspersed with sclerenchymatous groups. The median petiolar bundle has a sclerotic sheath which is perforated opposite the nectary (P1. XVI, Fig. 8). Calcium oxalate sphaerocrystals occur around the gland and mucilage cells are present in the leaf-epidermis. The petiole is of a rounded pentagonal form; the bundles of the upper angles are somewhat reduced.

\section{Polygonum scandens.}

The nectary is slit-like, measuring about $0.8 \times 0.75 \mathrm{~mm}$. Immediately beneath are two layers of sclerized and pitted cells, and between these and the bundle 3-4 layers of cells (Pl. XVI, Fig. 3).

The chief interest of this species lies in the fact that it possesses at once the smallest nectary and most reduced petiolar structure of all the species examined. The petiole, which has a deep groove on the upper surface, has six bundles; but two of these, situated in the wings bordering the groove, are extremely reduced (Pl. XVI, Fig. I2). What appear to be wax glands occur on the leaf-blade.

\section{Polygonum baldschuanicum.}

The nectary here is not well developed, and the lip is poorly differentiated; the underlying tissue is sclerized and pitted, and between this and the bundle is parenchymatous tissue. The petiole is rounded-pentagonal in outline; it contains six bundles, the upper two being small. An interesting feature of this species, which is a woody climber, is that nectaries are absent from the rosette of leaves at the base of the annual shoots; in some cases it was not till the eighth leaf that the nectary was present.

\section{Polygonum Convolvulus.}

This species has a somewhat small elongated nectary of triangular form about $0.9 \mathrm{~mm}$. long by $0.5 \mathrm{~mm}$. as its greatest breadth. The lips are 
well developed. Below the glands the tissue is strongly sclerized and pitted. The petiole is pentagonal in outline, the upper side being the longest; the bundles at the upper angles are somewhat smaller than the other four (Pl. XVI, Fig. IO).

\section{Polygonum cuspidatum.}

The nectary is oval in form and slightly concave transversely. The tissue beneath is strongly thickened and deeply pitted. The petiole is of oval-rectangular form with prominent ridges on either side of the upper surface. It contains from $8-9$ bundles.

\section{MICROCHEMICAL.}

In all the investigated species it was found that the tissue below the gland was rich in a substance which gave a blue reaction with hydrochloric and osmic acids. This was especially marked in the stalk cells, whilst the gland cells remained unchanged (Pl. XVI, Fig. II).

Heating sections with Fehling's solution gave a red precipitate in the gland cells only. But previous heating with $\mathrm{H}_{2} \mathrm{SO}_{4}$ and neutralization resulted in an instant reduction of the copper, which formed a copious precipitate in the epithem tissue between the nectary and the vascular bundle. Older non-secreting nectaries showed hardly any precipitate in the epithem. Ferric chloride gave a bluish precipitate in the epithem, but in the basal cells this was so marked as to render them almost black. Fehling's solution reduces the secretion itself without any previous treatment with acid.

The above results suggest the presence of a glucoside in the epithem tissue which by its breakdown supplies the glucose secreted from the nectary.

Concentrated sulphuric acid completely dissolves the sections placed in it except the cuticle, the gland cells, and the stalk cells. Sulphuric and iodine causes a brown coloration which is darkest for the stalk cells.

Concentrated caustic potash colours the stalk cells yellow, the tint becoming brighter on heating; the gland cells appear unchanged. Thus it would appear that the gland cells are cuticularized and the radial walls of the stalk cells are strongly suberized.

\section{Physiological.}

Most of the following experiments were performed upon plants in pots under glass. The experiments with saturated air were conducted on all species except $P$. scandens. The other experiments were chiefly carried out on $P$. cuspidatum and $P$. compactum.

Washing out young nectaries with water showed that these have the power of repeated excretion of fresh sugar, but after a while this ceases. 
If, however, fresh secretion from another nectary be placed upon the glands they function again.

Washing nectaries with O.I per cent. corrosive sublimate solution killed the gland cells, and no further secretion took place.

The same result obtained when the nectary was washed and the gland cells carefully scraped off with a scalpel.

The root pressure was determined for an actively secreting plant of $P$. cuspidatum, and was found to be equivalent to $I 3.1 \mathrm{~cm}$. of mercury. Water injected at a higher pressure only produced an increased secretion or rather bleeding from the lowest nectary of the shoot employed.

Secretion was equally active where the shoots were removed and placed with their cut ends in water.

Placing plants in saturated or nearly saturated air caused marked increase of secretion-this latter appearing as large drops clinging to the nectaries. The control plants showed no such increase. It was found that where the plants which were placed in saturated air possessed few shoots, and therefore few nectaries, the whole of the nectaries showed an increased activity.

But where large plants were used which bore numerous nectaries, only a few showed increased secretion.

One plant which bore fifty-two glands was placed in damp air. When examined after three hours only two nectaries were actively secreting.

The removal of eight leaves was followed after twelve hours by an increase in the number of actively secreting nectaries to six.

The result may have been due to an increase in the saturation, but a plant with a large number of nectaries, of which only three were secreting vigorously, showed an increase to only five after a lapse of sixty hours.

Where in the case of plants bearing numerous shoots one or two of these were enclosed in saturated air, whilst the remainder were in comparatively dry air, no increase of secretion was observed on the nectaries of the enclosed shoots.

Plants, which, in saturated air, had drops of secretion hanging to the nectaries, rapidly lost their drops on removal to dry air. In order to determine whether the loss of the drops was due to evaporation or absorption by the glands, control-drops of water of similar dimensions were placed on the axes and petioles. It was found that the drops of secretion were the first to disappear, notwithstanding their slower rate of evaporation in consequence of the dissolved sugar. We appear then to have glands here which, like those described by Kerner (10), are at once secretory and absorptive.

Experiments in saturated air were also performed upon the gumsecreting leaf-glands, and these too (particularly those of the ochrea) prove to be more active under that condition. 
This was most marked in $P$. sachalinense where the nodes of one young shoot were bathed in the gummy secretion which hung down in sticky threads.

With a view to finding if there were any relation between vascular supply and secretory area, the following table was constructed. Where the cross-sectional area of the xylem in the petiole of each species has been estimated, and the area of the corresponding nectary, it will be seen that the value obtained by dividing the one area by the other approaches a constant.

$\quad$ Species.
$P$. baldschuanicum
$P$. cilinodum
$P$. compactum
$P$. Convolvulus
$P$. cuspidatum
$P$. multiflorum
$P$. sachalinense
$P$. scandens

Approx. area
of nectary $(n)$.
$0.23 \mathrm{sq} . \mathrm{mm}$.
0.30 ", ",
$0.75, "$,
$0.22, "$,
$0.57,, \quad$,
$0.26, "$,
$2.25, "$,
$0.16,,$,

Approx. area of xylem in petiole $(x)$.

0.03 I sq. $\mathrm{mm}$.

$0.030,,$,

$0.076,,$,

$0.025,, \quad$,

$0.068,,$,

$0.028,, "$,

$0.247,$,

$0.019,,$,

Value $\frac{n}{x}$
$7 \cdot 4^{2}$
10.00
9.87
8.80
$8.5^{\mathrm{I}}$
9.29
$9 \cdot 1 \mathrm{I}$
$8.4^{2}$

\section{Summary and General Conclusions.}

The petiolar nectaries are in all cases surrounded by a lip which is raised and covered by thickened epidermal cells.

This lip, which projects most at the upper edge (Pl. XVI, Fig. I, l), may serve to protect the gland cells and to prevent the washing out of the nectary by rainwater. It may possibly further serve as a protection for the cells beneath against the plasmolyzing action of the osmotically powerful secretion contained in the nectary.

For it is these thick-walled lip cells with which the secretion is in contact. The tangential division of the epidermis of the lip which was observed in P. cilinodum still further supports this view. And in this connexion we may refer to the well-developed lip-structure described by Miss Ewart (6) in Ipomoea paniculata, as here, too, the lip exhibits a tangential division which may have the same significance.

A like function may be served by the suberization of the stalk cells, for the secretion has access to these notwithstanding the close packing of the glandular heads.

The high osmotic pressures involved may further account for the sclerization of the epithem cells, as the deep pittings, which are fairly numerous upon their surfaces, allow of sufficient facility for translocation. It is worthy of note that a similar pitted tissue has been observed below the gland cells of Ipomoea paniculata (6) which, as we have seen, closely resemble the glands of Polygonum in other respects. M. Vuillemin (16) has also called attention to the pitted tissue beneath the glands of the Tamariscineae, 
Plumbagineae, and Frankeniaceae, all of which secrete osmotically active substances.

The secretory activity of the nectaries appears to be due to osmotic action, largely independent of root pressure. The thin-walled character of the basal cells may be associated not only with the need for ready permeability, but also with communication of the turgor pressure of the surrounding tissue.

The experiments seem to show that the plant can accommodate itself to local inequalities of transpiration, and that these nectaries are, from the physiological point of view, water-secreting organs whose action is dependent upon osmosis.

To summarize the reasons for this view :

(1) The structure of the glandular trichomes agrees with that of the leaf-glands.

(2) The nectaries function at an early stage in the development of the organs upon which they are borne, and therefore at a period when excess of turgidity would be most injurious.

(3) There is a marked increase of secreted fluid accompanying an increase of humidity.

(4) The nectaries stand in close relation to the vascular bundles, and there is an increase in their number and extent accompanying an increase in complexity of the vascular supply. In those species which have a reduced petiolar vascular supply a reduced or simplified nectary is present.

(5) In no case were glands observed to be visited by ants, either in the exotic species at Kew, or in P. Convolvulus in its native haunts. In this latter some dozens of plants in various situations were kept under observation, and in no instance were they found to be visited by insects.

That some physiological purpose was served by extra-floral nectaries was suggested by Schimper (14). That this was, in the case of floral nectaries, of a hydathodal nature was advocated by Burck (4), and the same view in respect to floral nectaries has been put forward by Renner (12) and Schwendt (15, p. 42). The ant protection theory, whilst it is undoubtedly applicable in certain instances, has only been proved for a few. Aufrecht (2) and others have remarked on the absence of insects during their observations. Such protection must be regarded as an altogether secondary adaptation.

An admirable historical summary of the views regarding the function of extra-floral nectaries is given by Niewenhuis-Uxküll (11).

Bonnier (3) showed for floral nectaries that the maximum secretion took place when the soil and air were saturated.

Ono (12), who worked on numerous extra-floral nectaries including those of $P$. sachalinense and $P$. cuspidatum, summarized his results as follows. 'Among different external circumstances, moisture seems to be of the greatest importance' (p. 18). 
Burck (4) showed that the floral nectaries in many instances act as hydathodes, causing dehiscence of the anthers even in saturated air.

The frequent occurrence of extra-floral nectaries in tropical plants, where very sudden changes of humidity are often daily phenomena, cannot be without significance.

There does not, therefore, seem any difficulty, so far as known facts are concerned, in deriving all nectaries originally from osmotic hydathodes, subserving a physiological function, which have in certain cases secondarily acquired biological importance.

In conclusion, I should like to take this opportunity of recording my thanks to Professor F. W. Oliver, at whose suggestion and under whose direction the present work was undertaken.

\section{BIBLIOGRAPHY OF PAPERS REFERRED TO.}

1. Areschoug, F. W. C.: Untersuchungen über den Blattbau der Mangrove-Pflanzen, p. 33 . Stuttgart, 1902 .

2. Aufrecht, S. : Beiträge zur Kenntnis Exfl. Nek. Diss., Zürich, I89I, p. 26.

3. Bonnier, G. : Les Nectaires. Ann. des Sci. Nat., sér. 6, tom. viii, i878, p. I6I et seq.

4. Burck, W.: De l'influence des nectaires sur la déhiscence des anthères. Revue Générale de Bot., I907, Pp. I04-II.

5. Delpino, F.: Funzione mirmecofila nel regno vegetale. Mem. dell' Accad. Bologna, i888, p. 627 .

6. Ewart, M.: On the Leaf-glands of Ipomoea paniculata. Annals of Botany, pp. 275-88, vol. ix, I895.

7. Gardiner, W : The glands of Dionaea. Proc. Roy. Soc., vol. xxxvi, $1883^{-4}$, p. 180.

8. Haberlandt, G. : Physiologische Pflanzen-Anatomie, and ed., p. 420.

9. HuIE, L. : Changes in the cell organs of Drosera rotundifolia. Q.J.M.S., vol. xxxix, pp. I-38, Pls. XXIII and XXIV.

10. Kerner and Oliver: Nat. History of Plants, vol. i, p. 229.

11. Niewenhuis-Uxküll, M. : Exfl. Zuckerausscheidungen und Ameisenschutz. Ann. du Jardin Buitenzorg, vol. xxi, pp. 205-22, 1907.

12. Ono, K.: Studies on some Extranuptial Nectaries. Journal of the Coll. Sci. Imp. Univ. Tokyo, vol. xxiii, 1907 .

13. Renner, O. : Ueber Wachsdrüsen auf den Blättern und Zweigen von Ficus, Flora. Bd. xcvii, p. $37,1907$.

14. SAUnders, E. R. : Septal glands of Kniphofia. Annals of Botany, vol. v, p. i 7, i890-1.

15. Schimper, A. W. F.: Plant Geography, Eng. ed., p. I53, I903.

16. Schwendt, E. : Zur Kenntnis der Exfl. Nek. Beih. z. Bot. Centralblatt, Bd. xxii, 3, pp. 249-53, 1907.

17. Vuillemin, P.: Annales des Sci. Nat., Bot., sér. 7 , i 887 . Quelques glandes épidermiques, pp. $\mathbf{1}^{2} \mathbf{2}$ et seq. 


\section{EXPLANATION OF PLATE XVI.}

\section{Illustrating Mr. Salisbury's paper on the Nectaries of Polygomum.}

Fig. I. Polygonum cilinodum. Median longitudinal section through node. a.s. axillary shoot; $l$. lip of nectary ; och. ochrea; pet. petiole; scl. sclerenchyma; $t$. trichomes; v.t. vascular tissue. $\times \mathrm{I} 5$.

Fig. 2. P. cilinodum. Transverse section through nectary. s.c. stalk cells; scl. sclerenchyma; s.p. small-celled epithem; l.p. large-celled parenchyma. $\times$ I 78.

Fig. 3. P. scandens. Transverse section of nectary. $c r$. crystals of calcium oxalate; $l$. lip; t. trichomes; $v . b$. vascular bundle. $\times 35$.

Fig. 4. P. sachalinense. Longitudinal section of nectary. a.l. abscission layer; ep. epithem tissue; $t$. trichomes; v.b. vascular bundle. $\times 39$.

Fig. 5. P. scandens. Transverse section of young leaf. $g$. gum secreting gland. $\times 35$.

Fig. 6. P. sachalinense. Transverse section of petiole. $\times \mathrm{I} 2$.

Fig. 7. P. compactum. Transverse section of petiole. $\times \mathbf{I} 2$.

Fig. 8. P. multiflorum. Transverse section of nectary at upper end passing through the glandular area twice. scle. sclerized cell groups; $t$. trichomes; v.b. vascular bundle. $\times 35$.

Fig. 9. P. cilinodum. Transverse section of petiole. $\times \mathbf{I} 2$.

Fig. Io. P. Convolvulus. Transverse section of petiole. $\times \mathbf{I} 2$.

Fig. II. P. compactum. Transverse section of nectary taken after treatment with hydrochloric and osmic acids. $e p$. epithem; $l$. lip ; $t$. trichome; v.b. vascular bundle. $\times 27$.

Fig. I2. $P$. scandens. Transverse section of petiole. ch. ventral channel; p.b. phloem bundle. $\times 3 \mathrm{I}$. 
Annals of Botany.

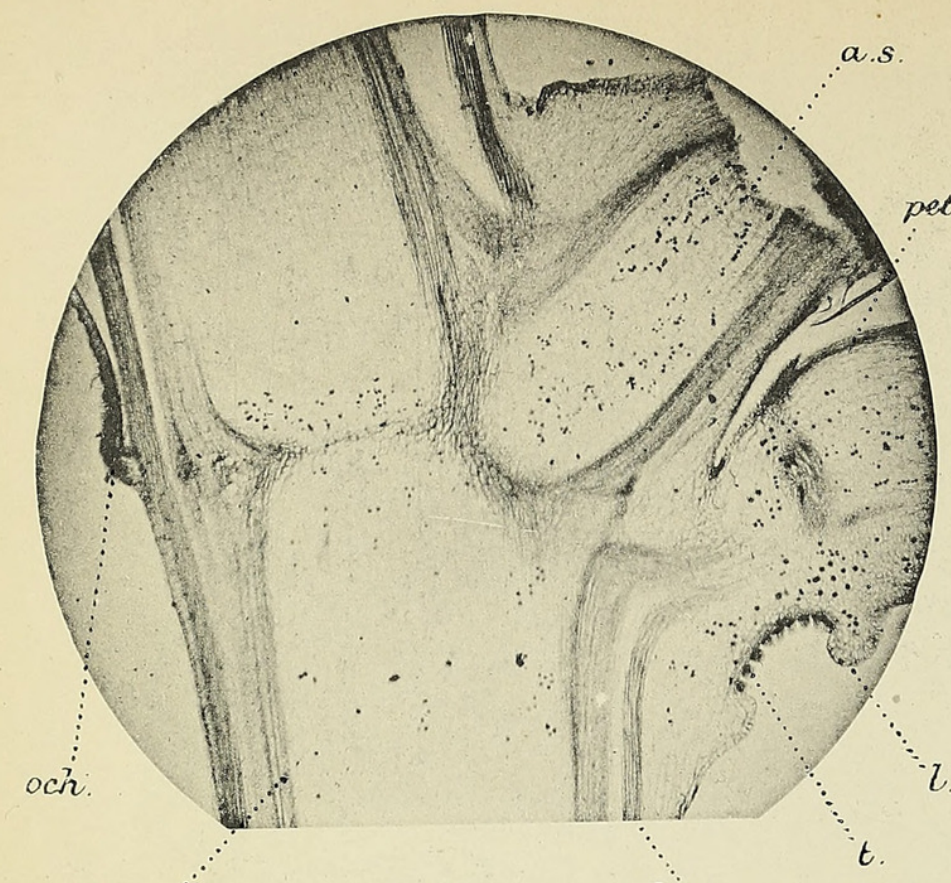

$V_{t}$

1.

Scl.

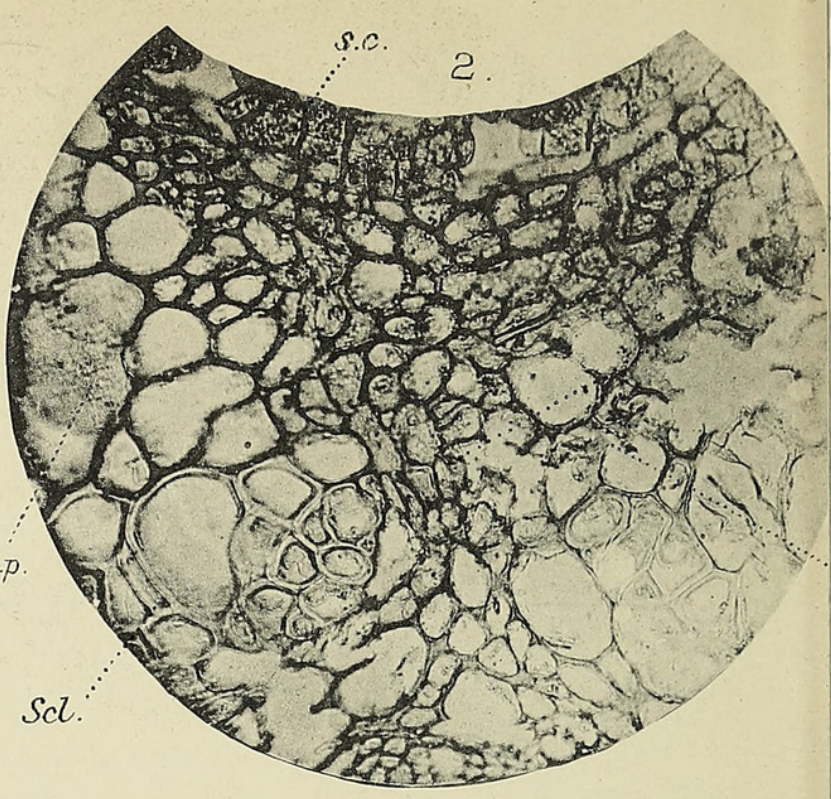

4.

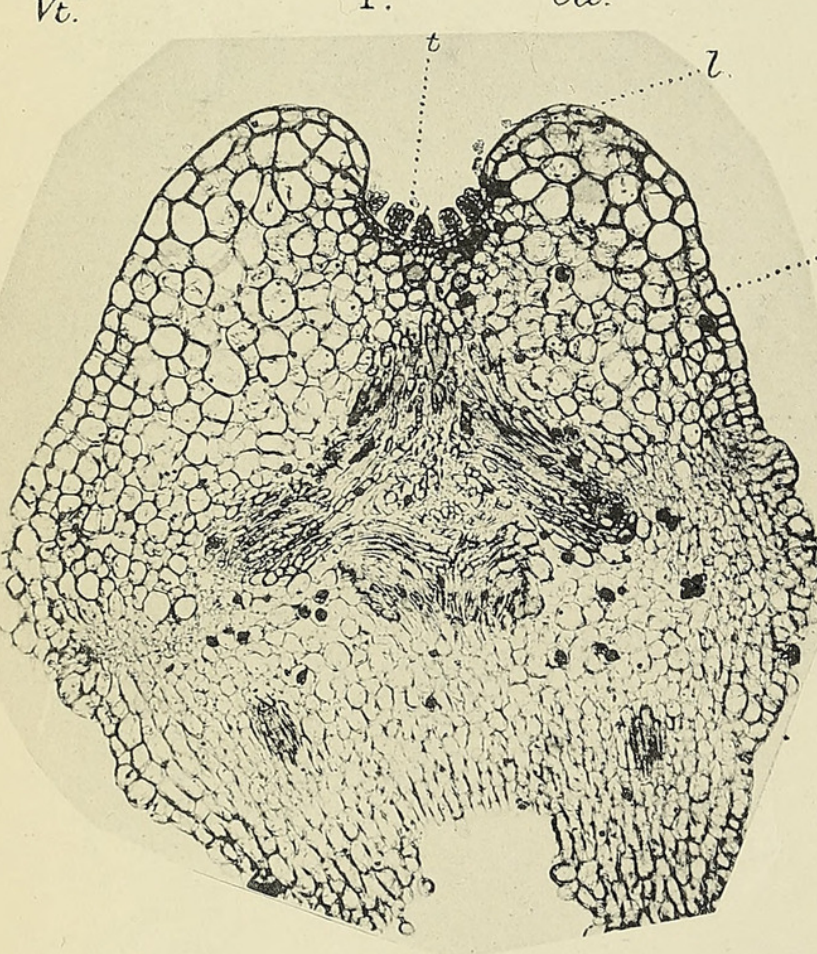

3.

V.b.
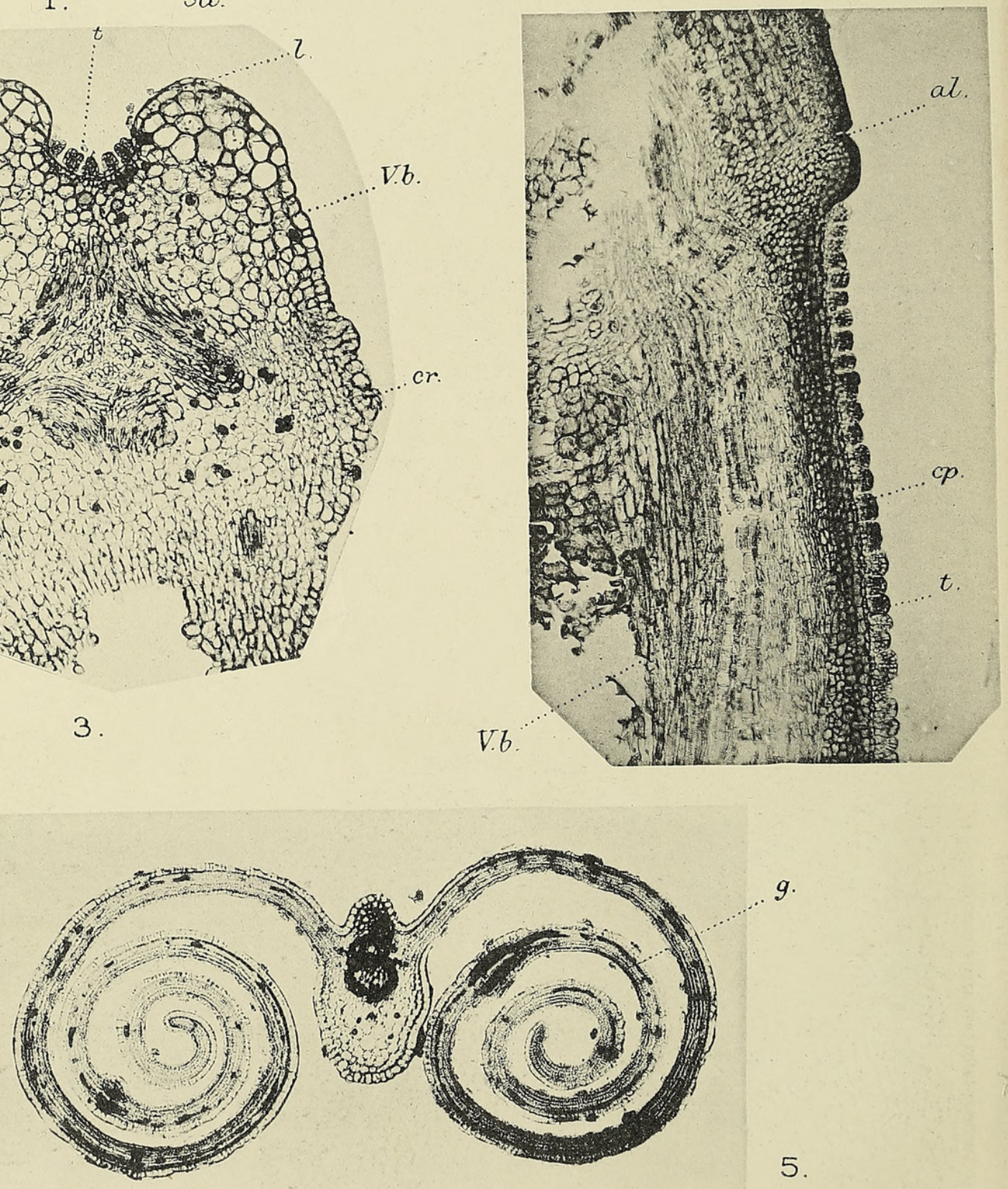

$g$. 

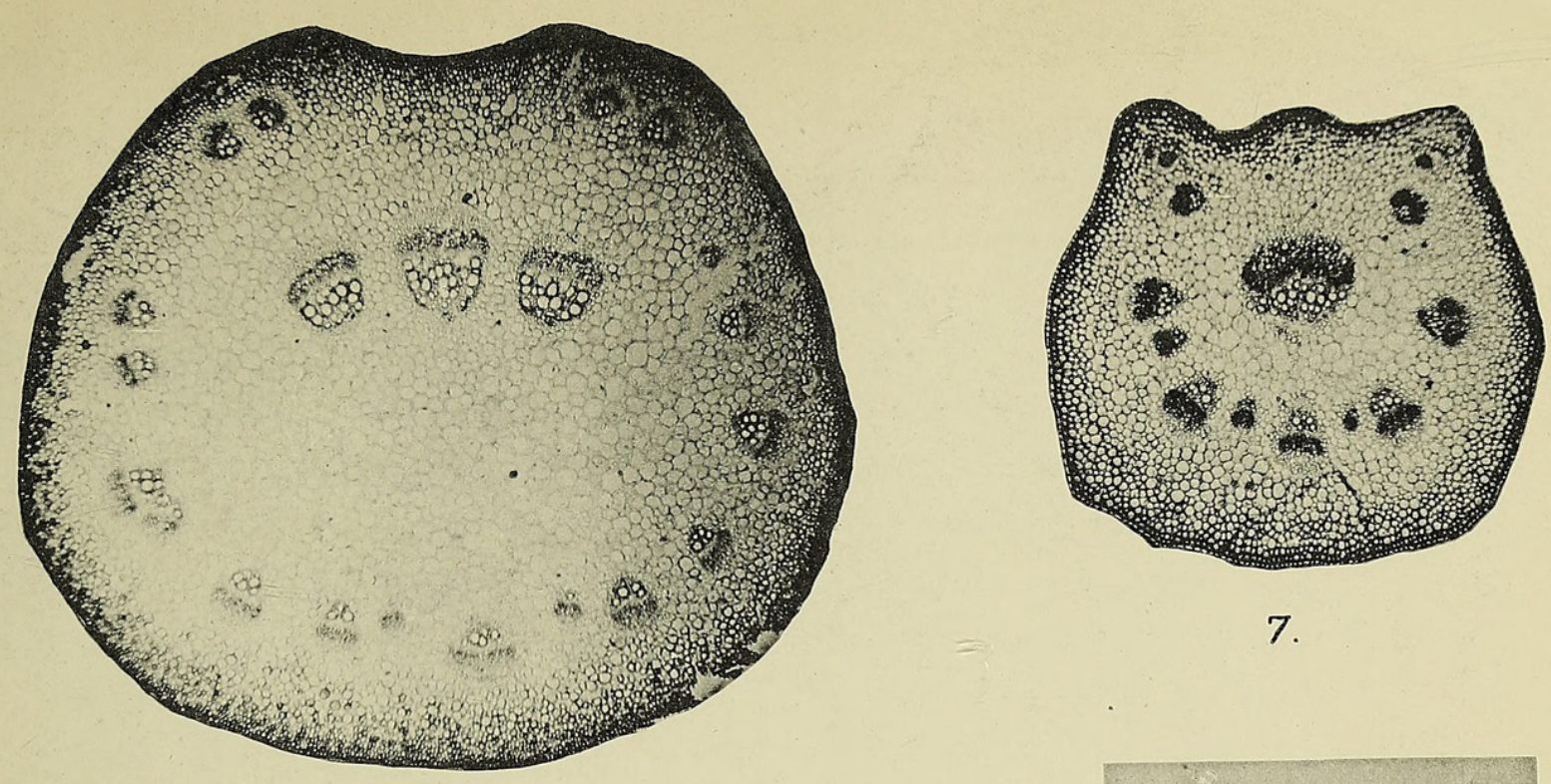

6
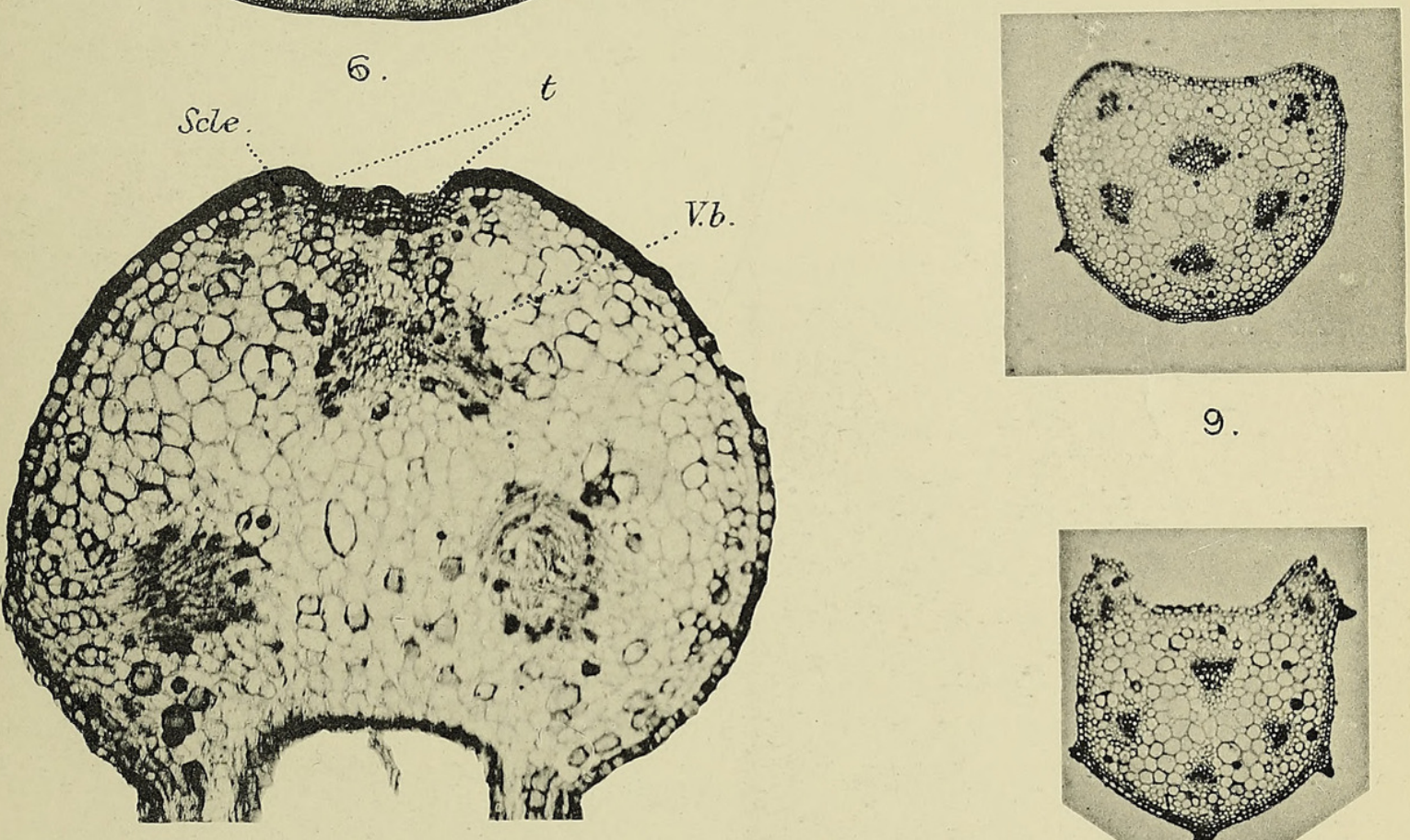

8

\section{9.}
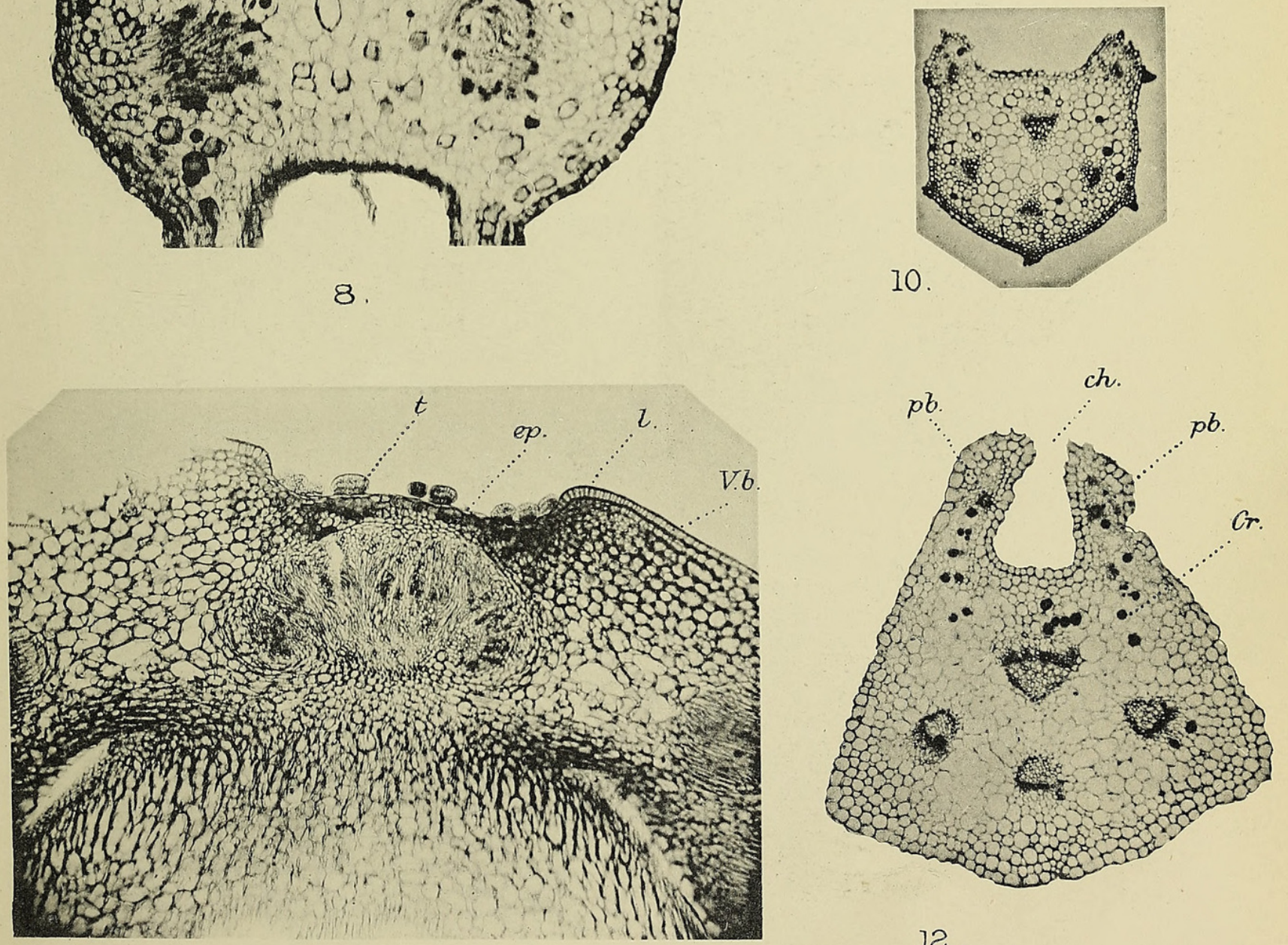

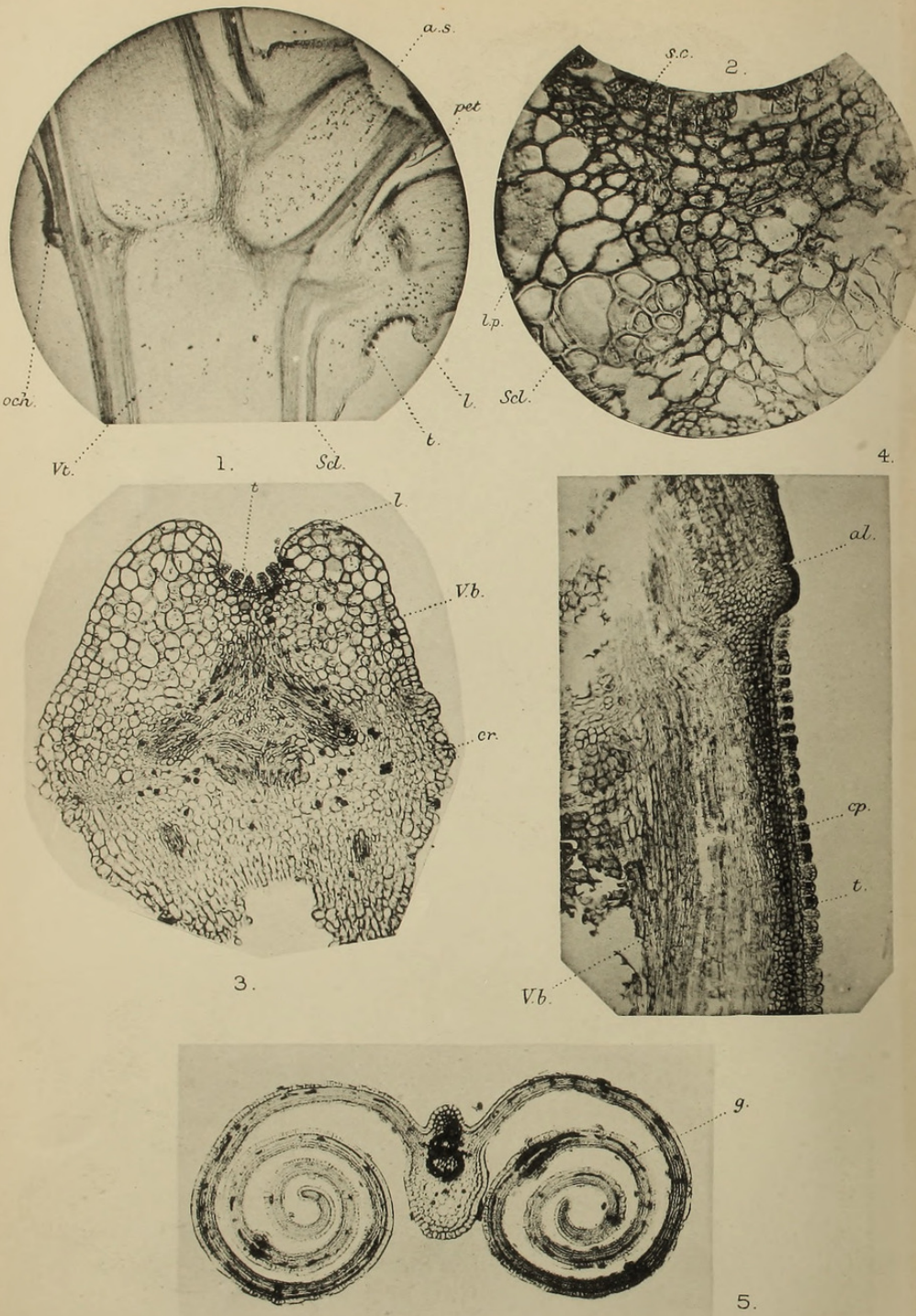

SALISBURY - EXTRA FLORAL NECTARIES OF POLYGONUM
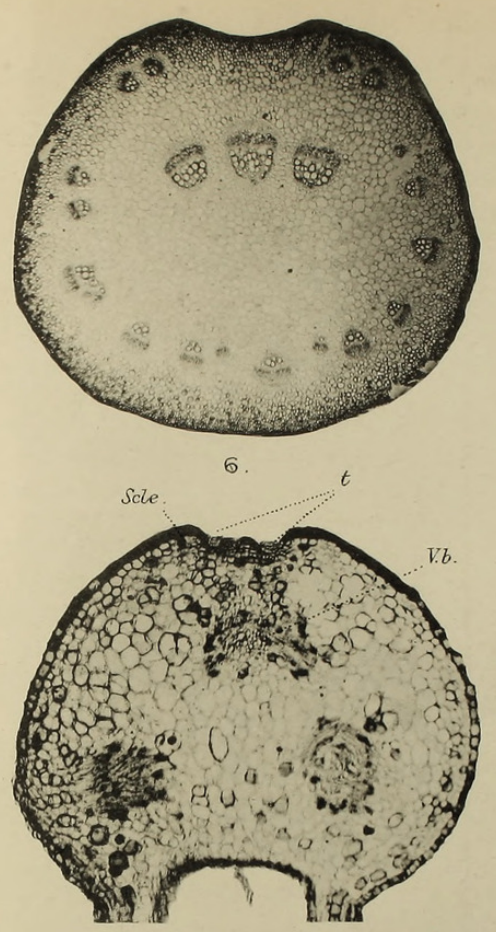

8.

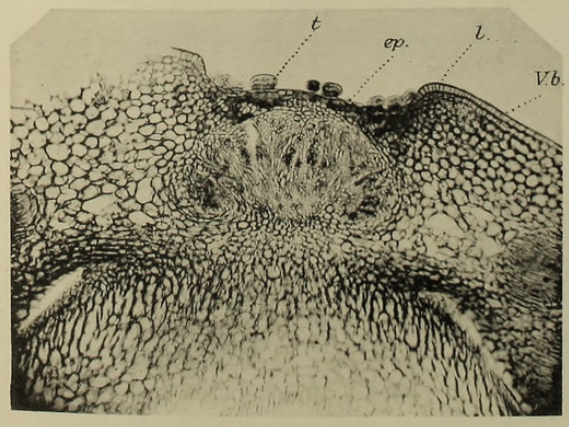

11
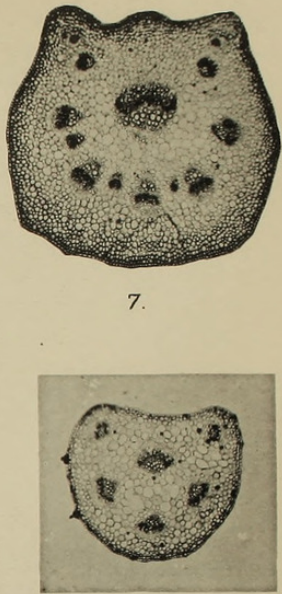

9
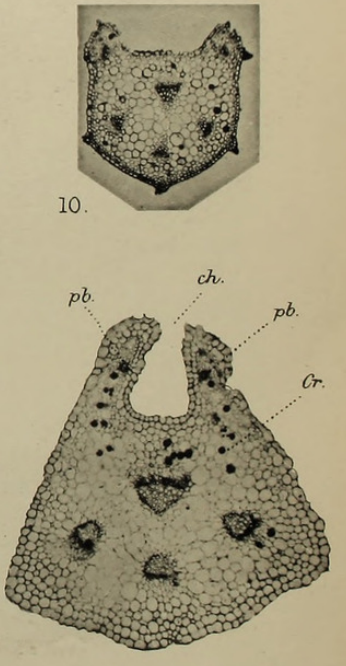

Huth coll 


\section{$2 \mathrm{BHL}$ Biodiversity Heritage Library}

Salisbury, E. J. 1909. "The extra-floral nectaries of the genus Polygonum." Annals of botany 23, 229-242.

https://doi.org/10.1093/oxfordjournals.aob.a089212.

View This Item Online: https://www.biodiversitylibrary.org/item/236540

DOI: https://doi.org/10.1093/oxfordjournals.aob.a089212

Permalink: https://www.biodiversitylibrary.org/partpdf/318948

\section{Holding Institution}

Smithsonian Libraries

\section{Sponsored by}

Biodiversity Heritage Library

\section{Copyright \& Reuse}

Copyright Status: Not in copyright. The BHL knows of no copyright restrictions on this item.

This document was created from content at the Biodiversity Heritage Library, the world's largest open access digital library for biodiversity literature and archives. Visit BHL at https://www.biodiversitylibrary.org. 